\title{
Effect of Voluntary Consumption of Fe Lactate Supplements on Development of Haematological Indices of Suckling Piglets
}

\author{
M. SVOBODA ${ }^{1}$, J. BOUDA ${ }^{2}$, M. KRAJÍČEK ${ }^{3}$, J. DRÁBEK ${ }^{1}$, J. DOUBEK $^{1}$, V. KOTRBÁČEK ${ }^{1}$ \\ ${ }^{1}$ University of Veterinary and Pharmaceutical Sciences, Faculty of Veterinary Medicine, Brno, Czech Republic \\ ${ }^{2}$ Facultad de Medicina Veterinaria y Zootecnica, Universidad Nacional Autónoma de México \\ ${ }^{3}$ Favea s.r.o. \\ Received June 28, 2004 \\ Accepted March 3, 2005
}

\begin{abstract}
Svoboda M., J. Bouda, M. Krajíček, J. Drábek, J. Doubek, V. Kotrbáček: Effect of Voluntary Consumption of Fe Lactate Supplements on Development of Haematological Indices of Suckling Piglets. Acta Vet. Brno 2005, 74: 199-204.

The objective of this study was to determine the efficiency of voluntary uptake of Fe lactate and lactate-based granular Fe mixture in the prevention of anaemia in suckling piglets. Group 1 (LaFe) of 29 piglets received Fe lactate in a loose form containing $142 \mathrm{~g} \mathrm{Fe}^{2+} / \mathrm{kg}$ on day 2 after birth. From day 2 of age group 2 (LaFeM) of 29 piglets had an access to a finely granular mixture, containing $70 \%$ of Fe lactate, $20 \%$ of lactoferrin and $10 \%$ of whey powder. The diet contained $99.5 \mathrm{~g} \mathrm{Fe} \mathrm{ge}^{2+} / \mathrm{kg}$. A small amount of vanilla flavour was added to this diet daily. The i.m. administration of Fedextran on day 3 after birth were carried out in group 3 (DeFe, 30 piglets, $200 \mathrm{mg} \mathrm{Fe}^{3+}$ ). Group 4 (An) of 20 piglets served as anaemic control. On day 7 after birth the piglets of $\mathrm{LaFe}, \mathrm{LaFeM}$ and An group had significantly lower values of $\mathrm{Hb}, \mathrm{PCV}, \mathrm{MCV}, \mathrm{MCH}$ and plasma Fe concentration compared to DeFe piglets $(P<0.01)$. There were not any large differences in $\mathrm{MCHC}$ values between the piglets. In week 2 after birth significant differences were measured also in RBC in favour of DeFe piglets $(P<0.01)$. After the administration of Fe dextran $\left(200 \mathrm{mg} \mathrm{Fe}^{3+}\right)$ to piglets in groups $\mathrm{LaFe}$ and LaFeM on day14 after birth the haematological values increased to the level of DeFe group. The live weight of DeFe piglets was higher than in the other groups $(P<0.01)$. The results indicate that the consumption of Fe lactate supplements was negligible and did not prevent anaemia of piglets.
\end{abstract}

Iron, anaemia, haemoglobin, red blood cell

Iron deficiency anaemia is a serious problem in swine production (Venn et al. 1947; Csapó 1995). An i.m. administration of $\mathrm{Fe}^{3+}$ in the form of dextran is the oldest and most frequently used method of prevention of Fe-deficiency anaemia in piglets. A dose of 200 $\mathrm{mg} /$ piglet is usually given at the age of 2-3 days (Heinritzi and Plonait 1997; Kle in beck and McGlone 1999). It is an invasive method that is not always free of complications such as iron poisoning (Süveges and Glávits 1976; Avram et al. 1982; Kolb and Hoffmann 1989). Iron ions must be bound to the protein transferrin in the organism. If its binding capacity is exceeded, free Fe is toxic. In connection with the i.m. administration of Fe the inhibition of macrophage activity (Kolb et al. 1992; Morris et al.; 1995, Lehmann 2001) and more frequent incidence of polyarthritis (Holmgren 1996) were reported. For these reasons further alternative methods of Fe supplementation are sought. Among others, it is the supply of iron in pastes, most frequently as Fe fumarate or recently as Fe lactate (Kotrbáček 2001; S voboda and Drábek 2002). As the absorption of $\mathrm{Fe}^{2+}$ is much better than that of $\mathrm{Fe}^{3+}$ (Dietzfelbinger 1987), only preparations containing bivalent iron are used for paste production. But a common disadvantage of this method of Fe administration is that it is labour-consuming and greatly disturb piglets and their mothers. Such complications would be fully eliminated by voluntary uptake of Fe preparations by piglets. Therefore this method has been tested for some time. For example, supplementation of

Address for correspondence:
MVDr. Martin Svoboda, Ph. D.
University of Veterinary and Pharmaceutical Sciences
Palackého 1-3, 61242 Brno
Czech Republic
Phone: +420541562433

E-mail: svobodama@vfu.cz

http://www.vfu.cz/acta-vet/actavet.htm 
feedwater with Fe preparations was tested (Zimmermann 1995; Egeli and Framstad 1998; Jörgensen and Brun 2000). As water intake in piglets after birth is low, it was an inefficient measure. The experience in the consumption of solid mineral supplements by piglets is different. Dubanský et al. (1997), Egeli and Framstad (1998) considered their use as problematic. The reason is the same as in aqueous solutions, i.e. a low consumption of solid feed in the first two weeks of piglet life. But not all tests of Fe uptake were negative. For example, Bohlmann and Schultze-Steinen (1966), Zimmermann 1995, Jörgensen and Brun (2000) reported that they prevented anaemia using preparations with high Fe content that were offered to piglets for voluntary consumption from day 2 after birth. The preparations had a high concentration of iron in the form of sulphate and fumarate. Fe lactate seems to be a suitable compound for this purpose. Iron is bound to an organic acid and its utilisation is good (Gebauer 1998). Tests with oral administration of lactate paste were successful (Kotrbáček 2001). It was also a reason why we tested the voluntary uptake of lactate as a way of Fe supplementation in piglets. From day 2 of life piglets were given either pure $10 \%$ Fe lactate or a mixture of lactate flavoured with whey powder and milk protein lactoferrin.

\section{Materials and Methods}

Experiments were conducted in a commercial farrowing house. Sows were transferred into farrowing pens a fortnight before parturition and stayed there until piglet weaning at the age of 28 days. Piglets were individually tattooed with number in the ear. Piglets from 11 litters comprising 108 animals were used in the study

Group 1 - LaFe group (3 litters, 29 piglets) received Fe lactate in a loose crystalline form, containing 142 $\mathrm{g} \mathrm{Fe}^{2+} / \mathrm{kg}$. The supplement was given from day 2 to day 14 of age.

Group 2 - LaFeM group ( 3 litters, 29 piglets) was given a finely granular mixture of Fe lactate (70\%), milk protein lactoferrin (20\%) and whey powder $(10 \%)$ in the same period. Dietary $\mathrm{Fe}^{2+}$ content was $99.5 \mathrm{~g} \mathrm{Fe}^{2+} / \mathrm{kg}$. To increase its palatability several drops of vanilla flavour were added to the mixture daily. At the end of week 2 after birth an i.m. application of $200 \mathrm{mg} \mathrm{Fe}^{3+}$ in the form of dextran to the piglets of the above two groups was carried out.

Group 3 - DeFe group (3 litters, 30 piglets) was given $200 \mathrm{mg} \mathrm{Fe}^{3+}$ i.m. in the form of dextran on day 3 after birth. Group 4 - An (anaemic) group (2 litters, 20 piglets) received the same supplementation on day 21 of age. Fe lactate mixtures were offered in shallow feeders at the place where the piglets stayed most frequently. In addition, from day 7 after birth the piglets had an access to feeders with a prestarter containing $248 \mathrm{mg} \mathrm{Fe} \mathrm{F}^{2+} / \mathrm{kg}^{\mathrm{B}} \mathrm{Blood}$ samples were taken on days 7, 14, 21 and 28 of piglet life. Blood was collected from the vena cava cranialis and following haematological values were determined in blood samples: haemoglobin concentration (Hb), packed cell volume (PCV), red blood count (RBC) and plasma Fe concentration. The following parameters were calculated from these values: mean corpuscular volume (MCV), mean corpuscular haemoglobin $(\mathrm{MCH})$ and mean corpuscular haemoglobin concentration (MCHC). Piglets were weighed at birth, and on days 7, 14, 21 and 28. Student's $t$-test was used for processing of the experimental data.

\section{Results}

The results are presented as mean values and standard deviations of each index in Figs 1-8. Group $1=\mathrm{LaFe}$ group, Group $2=\mathrm{LaFeM}$, Group $3=$ DeFe (dextran) group, Group $4=$ An (anaemic group) Values with $* P<0.05$ and $* * P<0.01$ express significant difference between dextran group (Group 3 ) and the two lactate groups (Group 1, Group 2).

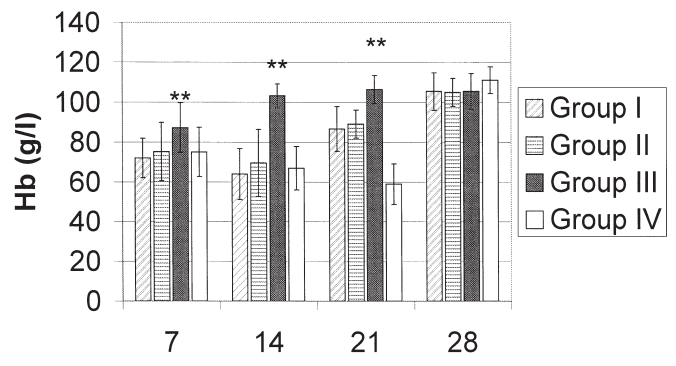

Fig. 1. Haemoglobin concentration $(\mathrm{Hb})$

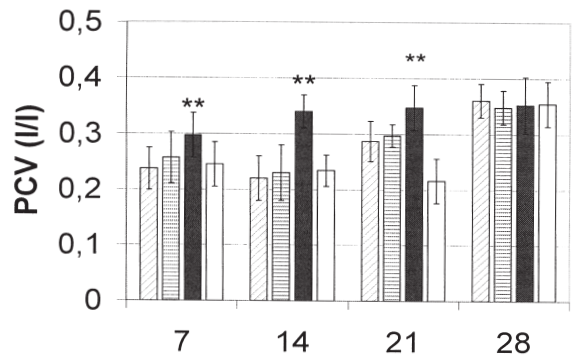

Fig. 2. Packed cell volume (PCV) 
At the end of week 1 after birth, compared to DeFe individuals, significantly lower values of $\mathrm{Hb}$ and PCV $(P<0.01)$ were measured in both lactate groups, i.e. in piglets that had an access either to Fe lactate only or to the finely granular mixture of Fe lactate. The $\mathrm{Hb}$ and PCV values of lactate-supplemented piglets did not differ from piglets of An group that did not receive any Fe in that period (Figs 1 and 2). The same situation repeated itself on day 14 after birth, but the difference between DeFe piglets and the other groups increased.

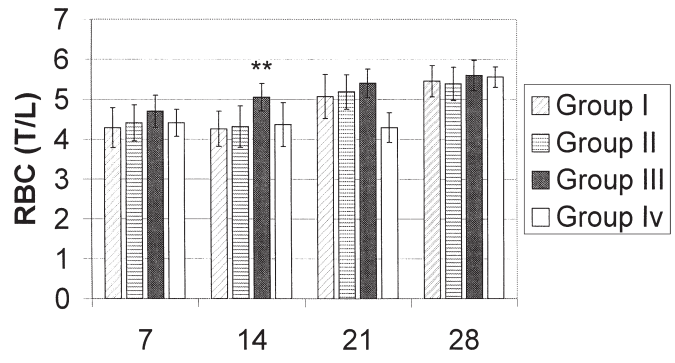

Fig. 3. Red blood cell count (RBC)

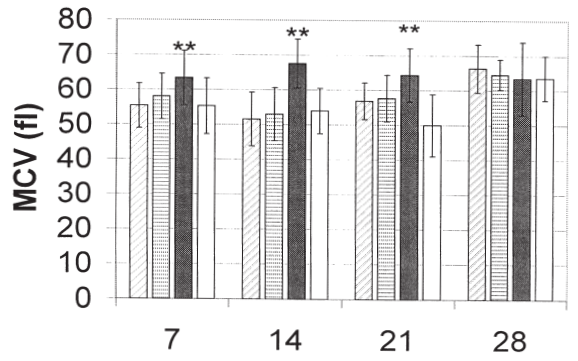

Fig. 4. Mean corpuscular volume (MCV)

The calculated haematological indices, especially MCV and MCH (Figs 4 and 5), also showed the same trend in the first 14 days. The MCHC did not change practically (Fig. 6). Differences in RBC were measured in 14 days old piglets only (Fig. 3). All haematological parameters rapidly increased in these piglets after the i.m. application of $200 \mathrm{mg} \mathrm{Fe}^{3+}$. Even though they did not reach the level of DeFe group at the end of week 3, in the subsequent age category on day 28 after birth they were fully identical with this group. In the piglets of An group, which was supplemented with $200 \mathrm{mg} \mathrm{Fe}^{3+}$ as late as on day 21 after birth, the haematological values continued to decrease in the third postnatal week as expected. The level of plasma Fe determined on day 7 after birth in both lactate groups was 5 times lower than in DeFe piglets. Marked differences were observed also at the end of week 2 of age (Fig. 7). After the i.m. injection of $\mathrm{Fe}^{3+}$ to the lactate groups on day 14 after birth the plasma Fe concentration increased rapidly to the level of DeFe piglets.

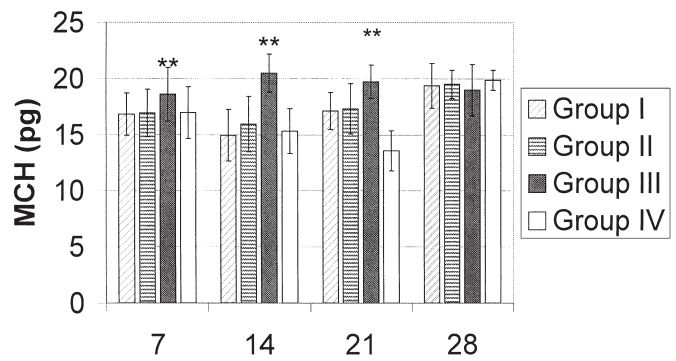

Fig. 5. Mean corpuscular haemoglobin (MCH) (MCHC)

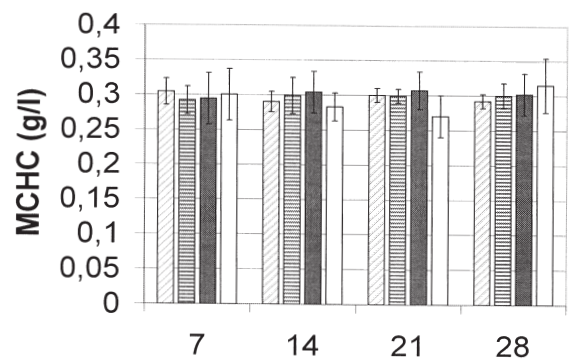

Fig. 6. Mean corpuscular haemoglobin concentration

Iron deficit in lactate-supplemented piglets significantly influenced their live weight growth. On day 14 after birth $\mathrm{DeFe}$ animals with timely i.m. supplementation had significantly higher live weight $(P<0.01)$ (Fig. 8). A significant weight difference between this group and other groups persisted by the end of experimental period. 


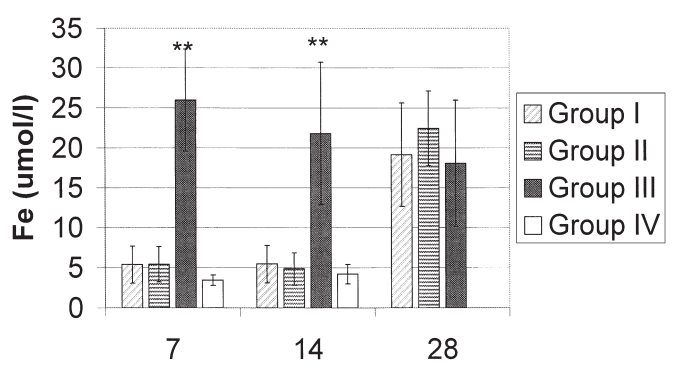

Fig. 7. Iron concentration in blood plasma (Fe)

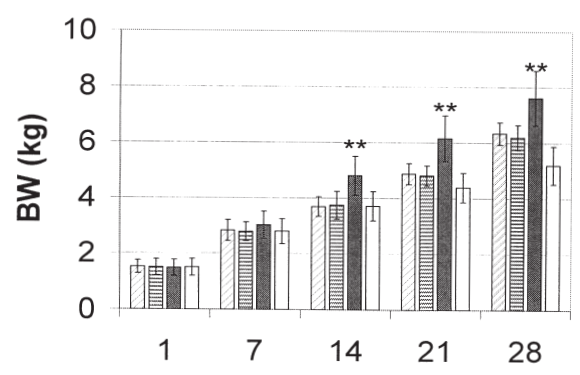

Fig. 8. Body weight (BW)

\section{Discussion}

The experimental results indicated that symptoms of anaemia developed in piglets with access to lactate diets at the end of week 1 after birth. The main indicator is a decrease in $\mathrm{Hb}$ concentration below the level of $80 \mathrm{~g} / \mathrm{l}$ that is considered as an anaemic limit (Furugouri 1975; van Kempen 1987; Egeli et al. 1998). Decreasing values of Hb were also measured in the subsequent week after birth. Clinical signs of anaemia (pale mucosal membranes, pale skin all over the body surface) were observed and the piglets had to be treated with Fe dextran (200 mg Fe, i.m.). As identical results were obtained in piglets without Fe supplementation in that period, it can be stated that the voluntary uptake of lactate diets was negligible. Our results agree with the findings of Dubanský et al. (1997) and Egeli and Framstad (1998), who concluded that young piglets were not able to ingest enough solid feed that could be a source of Fe for normal growth and development. The course of PCV values in the first two weeks was identical with $\mathrm{Hb}$ concentration. The results also documented a significant decrease in $\mathrm{MCH}$ due to Fe deficiency. As the average size of erythrocytes (MCV) was reduced at the same time, their haemoglobin concentration (MCHC) remained unchanged. It means that in spite of $\mathrm{Hb}$ deficiency, the stable concentration of haemoglobin in erythrocytes is maintained if their size is reduced. This trend was also observed in group 4 , in so called anaemic group. But a highly significant difference in $\mathrm{MCHC}$ were observed between An and DeFe group at the end of week 3 after birth, when the Hb concentration decreased below $60 \mathrm{~g} / \mathrm{l}$. A reduction in the erythrocyte size that was already described by Egeli and Framstad (1998) and the MCHC stabilisation we identified as an adaptive response to $\mathrm{Hb}$ deficiency are apparently essential for the function of erythrocytes. It can also imply other positive aspects. If the erythrocyte counts do not decrease markedly, their total surface is still relatively high. It is advantageous for $\mathrm{O}_{2}$ bond. In addition, smaller erythrocytes pass through the capillary network and through the spleen sinuses more easily; it can have a positive influence on their life span. A smaller decrease in RBC compared to the other parameters would prove this conclusion. In this context the maintenance of erythrocyte deformability is extraordinarily important. Their ability to change their shape is ascribed to the properties of the membrane. It also depends on the water to solids content ratio - i.e. on the haemoglobin content in the cell. As the value of $\mathrm{MCH}$ decreased proportionately to a decrease in $\mathrm{MCV}$, it can be concluded that the hydration of cells was maintained. After a sudden influx of injection Fe, either in both lactate groups or in the anaemic group, there was a rapid increase in $\mathrm{Hb}$ concentration and in the other examined parameters including the level of plasma Fe.

Besides the above described haematological changes there was a standard somatic response. Fe deficiency led to a rapid onset of growth depression. Growth depression in iron deficient piglets was also reported by other authors (Egeli et al. 1998; Svoboda and Drábek 2002). A decrease in the synthesis of myoglobin can be considered as a mechanism 
sparing $\mathrm{Fe}$ for its vital functions in $\mathrm{O}_{2}$ transfer. It is interesting that the differences that arose in weight between the piglets were not compensated until weaning even though the sufficient supply of Fe resulted in a rapid adjustment of all haematological values. A conclusion can be drawn that the timely supplementation of Fe in a suitable form is essential in order to utilise the high growth ability of piglets that is typical of the first weeks after birth. Apparently, it will always be risky to rely on the voluntary uptake of dietary Fe in this period.

\section{Vliv dobrovolného př́ijmu laktátu železa na vývoj hematologických ukazatelů sajících selat}

Cílem práce bylo zjistit účinnost voluntárního příjmu laktátu železa pro prevenci anémie sajících selat. Ve skupině 1 (LaFe, 29 selat) byl selatům předkládán laktát železa s obsahem $142 \mathrm{~g} \mathrm{Fe}^{2+} / \mathrm{kg}$. Skupině 2 (LaFeM, 29 selat) byla předkládána směs obsahující $70 \%$ laktátu $\mathrm{Fe}, 20 \%$ laktoferrinu a $10 \%$ syrovátky. Směs obsahovala $99.5 \mathrm{~g} \mathrm{Fe}^{2+} / \mathrm{kg}$. Ke směsi bylo každý den přidáváno vanilkové aroma. Selatům ve skupině 3 (DeFe, 30 selat) byl 3. den po narození aplikován dextran železa (200 mg Fe ${ }^{3+}$, i.m.). Skupina 4 (An, 20 selat) sloužila jako anemická kontrola. Sedmý den po narození měla selata z LaFe, LaFeM a An skupin signifikantně nižší hodnoty $\mathrm{Hb}, \mathrm{PCV}, \mathrm{MCV}, \mathrm{MCH}$ a koncentrace Fe v plazmě ve srovnání se selaty ze skupiny DeFe $(P<0.01)$. Žádné signifikantní rozdíly nebyly zjištěny v hodnotě MCHC. Druhý týden po narození selat byl zjištěn v DeFe skupině i vyšší počet erytrocytů ve srovnání s ostatními skupinami $(P<0.01)$. Tělesná hmotnost selat v DeFe skupině byla větší než v ostatních skupinách $(P<0.01)$. Selatům z laktátových skupin (LaFe, LafeM) byl aplikován 14. den po narození léčebně dextran $\mathrm{Fe}\left(200 \mathrm{mg} \mathrm{Fe}^{3+}\right.$, i.m.). Po této aplikaci došlo ke zvýšení hematologických parametrů na úroveň DeFe skupiny. Zjištěné výsledky ukazují, že prŕíjem laktátu Fe selaty byl zanedbatelný a nezabránil vzniku anémie selat.

\section{Acknowledgements}

The study was supported by the project MSM 6215712403.

\section{References}

AVRAM N, MACONEI N, ZABAVA R, VOINEA GV 1982: Adverse reactions in piglets injected with iron dextran for prevention of anaemia. Rev. Crest. Animalelor, Bucuresti 11: 45

BOHLMANN, W, SCHULTZE-STEINEN, H 1966: Über die Wirksamkeit der Anämieprophylaxe bei Saugferkeln. Zentbl Veterinärmed (B) 13: 119-124

CSAPO JE 1995: Protein, fats, vitamins and mineral concentration in porcine colostrum and milk from parturtion to 60 days. Int Dair J 6: 881-902

DIETZFELBINGER H 1987: Bioavailability of bi- and trivalent oral iron preparations. Investigations of iron absorption by post-absorption serum iron concntration curves. Arzneimittelforschung: 37: 107-112

DUBANSKÝ V, ŽIŽLAVSKÝ M, CHLOUPEK J 1997: Poruchy buněčné a humorální imunity selat v důsledku nesprávné aplikace Fe. Veterinářství 10: 413-417

EGELI AK, FRAMSTAD T 1998: Effect of oral starter dose of iron on haematology and weight gain in piglets having voluntary access to glutamic acid-chelated iron solution. Acta vet Scand 39: 359-365

EGELI AK, FRAMSTAD T, MORBERG H 1998: Clinical biochemistry, haematology and body weight in piglets. Acta vet Scand 39: 381-393

FURUGOURI K 1975: Characteristic aspects of iron metabolism in piglets. Jap Agric Res Q 9: 171

GEBAUER K 1998: Metabolická využitelnost minerálních látek. Náš chov 6: 28-29

HEINRITZI K, PLONAIT H 1997: Blutkrankheiten. In Lehrbuch der Schweinekrankheiten, $2^{\text {nd }}$ ed., Ed. H. Plonait, K. Bickhardt, Parey Buchverlag Berlin, p. 190

HOLMGREN N 1996: Polyarthritis in piglets caused by iron dextran. In: Proc IPVS Congress, Bologna, p. 306

JÖRGENSEN A, BRUN E 2000: Haematological status in 3 week piglets in herds with different strategies for iron supply. Proc. $16^{\text {th }}$ IPVSC, Melbourne, p. 192

KLEINBECK S, MCGLONE J 1999: Intensive indoor versus outdoor production systems: Genotype and supplemental iron effects on blood haemoglobin and selected immune measures in young pigs. J Anim Sci 77: 2384-2390

KOLB E, HOFFMANN U 1989: Zur Frage der zweckmässigen Form der Anwendung von Fe-dextran, seiner Verwertung sowie des Mechanismus einer möglichen Schädigung der Ferkel. Mh Vet Med 44: 497-501 
KOLB E, HOFFMANN U, NESTLER K 1992: Untersuchungen über den Gehalt an Eisen, Kupfer und Zink in verschiedenen Geweben (Magen-Darm-Kanal, Lymphknoten, Muskulatur, Herz, Leber, Milz, Niere, Pankreas, Knochenmark) bei neugeborenen Ferkeln nach oraler und intramuskulare Verabreichung von Fe-Dextran. Mh Vet Med 47: 271-278

KOTRBÁČEK V 2001: Effect of different formulae for oral and parenteral administration of iron on somatic growth and selected haematological indexes in piglets. Czech J Anim Sci 46: 49-54

LEHMANN P 2001: Anaemia: A major medical problem in the world. Eur Clin Lab 20: 26-30

MORRIS CJ, EARL JR, TRENAM CW, BLAKE DR 1995: Reactive oxygen species and iron - a dangerous partnership in inflammation. Int J Biochem Cell Biol 27: 109-122

SVOBODA M, DRÁBEK J 2002: Effect of oral administration of $\mathrm{Fe}^{2+}$-fumarate on erythrocyte profile and growth rate of suckling piglets. Acta Vet Brno 71: 217-222

SÜVEGES T, GLÁVITS R 1976: Piglet losses due to parenteral application of iron-dextran preparations. Acta Vet Hung 26: 257-262

VAN KEMPEN, GJM 1987: Avoid iron deficiency in piglets. Pigs 3: 10-11

VENN JAJ, MCCANCE RA, WIDDOWSON EM 1947: Iron metabolism in piglet anemia. J Comp Path 57: 314-325

ZIMMERMANN W 1995: Auswirkungen diverser Anämieprohylaxeformen auf die Blutparameter der Saugferkel. Dtsch tierärzt Wschr 102: 32-38 